doi: $10.15407 /$ ujpe62.10.0908

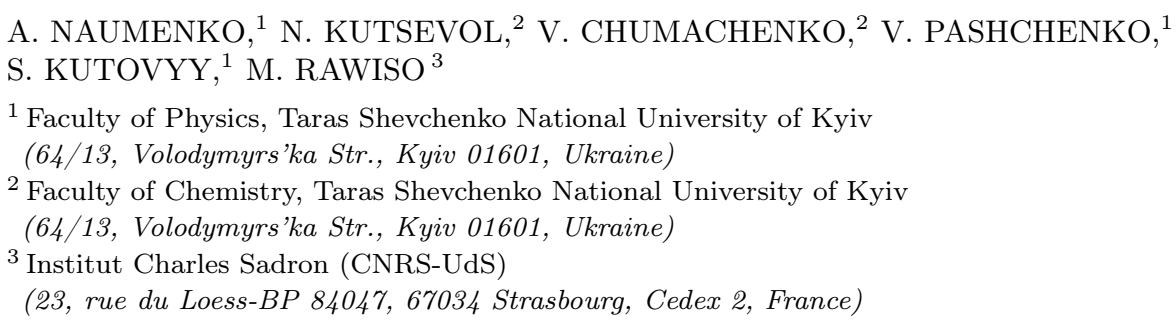

\title{
SYNTHESIS AND CHARACTERIZATION
} PACS 71.20.Nr, 78.55..m, OF CdS NANOPARTICLES OBTAINED IN STAR-LIKE $\begin{array}{ll}78.67 \pm \mathrm{n}, 81.05 . \pm \mathrm{t}, & \text { DEXTRAN-GRAFT-POLYACRYLAMIDE MATRICES } \\ 81.07 . \pm \mathrm{b} & \end{array}$

\begin{abstract}
Cadmium sulfide (CdS) nanoparticles (NPs) are synthesized into a branched dextran-graftpolyacrylamide matrix. The obtained stable sol is characterized by spectrophotometry, fluorescence spectroscopy, transmission electron microscopy, and dynamic light scattering. The polymer affects the process of the nanoparticle formation, namely controls their size and morphology, and enhances the sols storage stability preventing the nanoparticles aggregation. It is shown that $C d S$ NPs obtained in a branched polymer matrix are monodisperse 4-6 nm in size and form clusters (50-200 $\mathrm{nm}$ in size) localized in a limited macromolecule volume. The CdS nanoparticles reveal the improved blue light emission and may be considered as a promising material for light-emitting devices, especially in the blue region. They may have potential applications as biological labels.
\end{abstract}

Ke ywords: nanoparticles, absorption spectra, fluorescence spectra, transmission electron microscopy, polymer matrix.

\section{Introduction}

Semiconductor nanoparticles have attached much attention during the past decade due to their unique size-dependent luminescence, optical, and electrical properties [1-3]. CdS nanoparticles belong to the group of chalcogenides and show a very high surfaceto-volume ratio and are quantum confident on the nanoscale. $\mathrm{CdS}$ is one of the most studied materials with a band gap of $2.4 \mathrm{eV}$ [4]. It is primarily used in solar cells and a variety of electronic devices. CdS nanoparticles also have very high photo-

(C) A. NAUMENKO, N. KUTSEVOL,

V. CHUMACHENKO, V. PASHCHENKO,

S. KUTOVYY, M. RAWISO, 2017 sensitivity that makes them a promising candidate for the detection of visible radiation. They enhance the efficiency of solar cells and are used in LEDs and a number of biological applications. In the recent years, a great attention was focused on the synthesis of the nanocrystals containing $\mathrm{Cd}$ directly inside of a polymeric matrix [5-7] and using biological systems [8-10]. The photo-conductive and electroluminescent properties of cadmium sulfide have been applied in manufacturing a variety of consumer goods. That is why the simple synthesis of semiconductor nanoparticles is crucially important not only for the study of their physical properties, but also for the industrial application in the area of catalysts, photo-catalysts, and microelectronics.

ISSN 2071-0194. Ukr. J. Phys. 2017. Vol. 62, No. 10 
The size and shape of NPs are actually controlled by the synthesis condition [11]. Due to a high reactivity of NPs, the preparation of stable nanosystems requires a protection agent preventing the possible aggregation process [12]. Polymers enhance the stability of nanoparticles by introducing steric and/or electrostatic repulsions between them. On the other hand, polymers can also play a significant role in the process of nanoparticle formation, namely they can control their size and morphology [13].

In the present paper, the characterization of cadmium sulfide nanoparticles synthesized into branched polymer matrices has been studied.

\section{Experimental Details}

\subsection{Materials}

$\mathrm{CdSO}_{4}, \mathrm{Na}_{2} \mathrm{~S}$, and $\mathrm{NaBH}_{4}$ were purchased from Sigma-Aldrich, Germany and used without additional purification. The branched star-like copolymer dextran-g-polyacrylamide (D-g-PAA) was as a matrix for the synthesis of CdS nanoparticles. The polymer plays the role of a matrix, by acting as nucleating, capping, and stabilizing agents simultaneously.

The copolymer was obtained by the free-radical polymerization initiated by a ceric ion reducing agent. Namely, the polyacrylamide chains were grafted onto the dextran core $\left(M w=7 \times 10^{4} \mathrm{~g} / \mathrm{mol}\right)[14,15]$. The redox process initiates free radical sites exclusively on the polysaccharide backbone, thus preventing the formation of PAA homopolymers [15].

The synthesis, identification, and analysis of the polymer average structure were described in [14, 15]. The theoretical number of grafting sites per dextran backbone for the sample we used in the present work was equal to 5 . The molecular characteristics of the branched polymer are: $M w=1.57 \times 10^{6} \mathrm{~g} / \mathrm{mol}$, $M w / M n=1.81$, and $R_{g}=85 \mathrm{~nm}$.

This copolymer has star-like structure consisting of a compact dextran core and long polyacrylamide arms $[14,15]$. It was reported in our previous study that branched polymers were much more efficient for the synthesis of silver nanoparticles [16-18]. The structure peculiarities of branched polymers caused a higher local concentration of functional groups in comparison with their linear analogue, giving the advantages for the application of branched polymers as matrices in nanotechnologies.

ISSN 2071-0194. Ukr. J. Phys. 2017. Vol. 62, No. 10

\subsection{Synthesis of CdS nanoparticles}

The synthesis of CdS nanoparticles was carried out in a solution of the polymer at room temperature $\left(25^{\circ} \mathrm{C}\right)$. Stock solution of $\mathrm{CdSO}_{4}(0.1 \mathrm{M})$ and $\mathrm{Na}_{2} \mathrm{~S}$ $(0.1 \mathrm{M})$ in deionized water was prepared. A $0.9 \mathrm{ml}$ portion of $\mathrm{CdSO}_{4}$ was added to $20 \mathrm{ml}$ of the aqueous polymer solution $\left(c=1 \times 10-3 \mathrm{~g} / \mathrm{cm}^{3}\right)$, the mixture was stirred for $15 \mathrm{~min}$, then $0.9 \mathrm{ml}$ of $\mathrm{Na}_{2} \mathrm{~S}$ stock solution was injected under stirring. The resulting stable yellow CdS colloid was characterized in $24 \mathrm{~h}$ and then remained essentially unchanged for 4 months.

\subsection{Characterization}

UV-visible absorption spectra of sols were collected using a Specord UV-Vis (Analytic Jena) spectrophotometer over a wavelength range from 300 to $800 \mathrm{~nm}$. Original solutions were diluted 25 times before spectral measurements. The estimation of the average sizes of nanoparticles from the absorption spectra was performed using the effective mass approximation $[17,18]$.

Fluorescence spectra were recorded using a Cary Eclipce spectrofluorometer (Varian) in a quartz cell $(1 \times 1 \mathrm{~cm})$. The source was a xenon lamp pulsed at 80 $\mathrm{Hz}$ with exceptionally long lifetime. The pulses had the width at a half-peak height $\sim 2 \mu \mathrm{s}$, the peak power is equivalent to $75 \mathrm{~kW}$.

Transmission Electron Microscopy. For the sample preparation, 400 mesh $\mathrm{Cu}$ grids with a plane carbon film were rendered hydrophilic by a glow discharge treatment (Elmo, Cordouan Technologies Bordeaux France). A $5 \mu$ l drop was deposited and let adsorbed for $1 \mathrm{~min}$. Then the excess of the solution was removed with a filter paper piece. The observations of Ag NPs were carried on two TEMs, Tecnai G2 or CM12 (FEI, Eindhoven, Netherlands), and the images were acquired with a ssCCD Eagle camera on the Tecnai and a Megaview SIS Camera on the CM12.

Quasielastic Light Scattering (QELS). The Dynamic Light Scattering (DLS) measurements were carried out using a Zetasizer Nano ZS90 (Malvern Instruments Ltd., UK). The apparatus contains a 4$\mathrm{mW} \mathrm{He}-\mathrm{Ne}$ laser with a wavelength of $632.8 \mathrm{~nm}$, and the scattered light is detected at an angle $60^{\circ}$. The inverse Laplace transformation of experimental correlation functions was performed using the MathLab code rilt.m [http://www.mathworks.com/matlabcentral/ fileexchange/6523-rilt/content/rilt.m]. 


\section{Results and Discussion}

CdS nanoparticles have been prepared by the coprecepitation method in an aqueous solution of graft copolymers Dextran-Polyacrylamide (D-g-PAA). The TEM image analysis confirms the existence of single CdS particles 4-6 $\mathrm{nm}$ in size, as well as the aggregates of percolated particles (Fig. 1). Individual CdS nanoparticles are well defined and are nearly

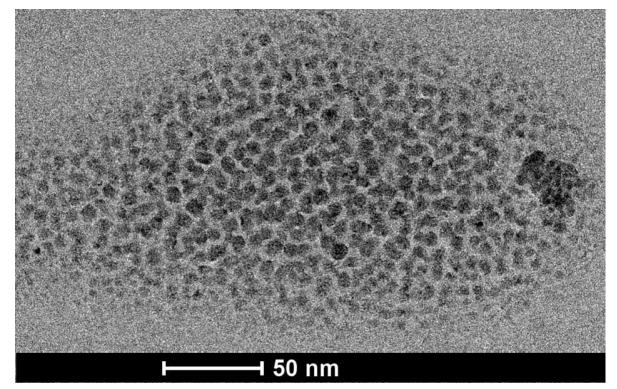

$a$

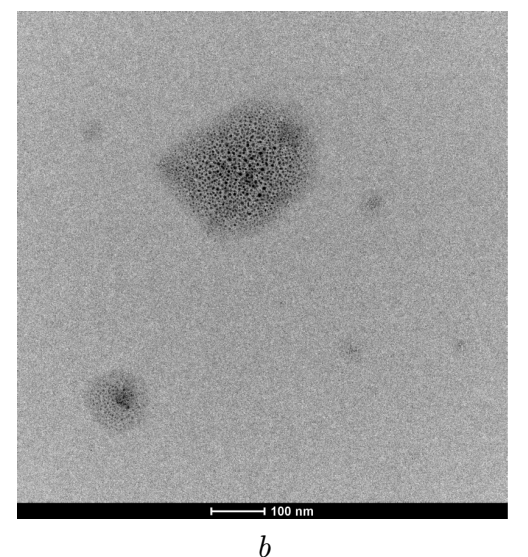

$b$

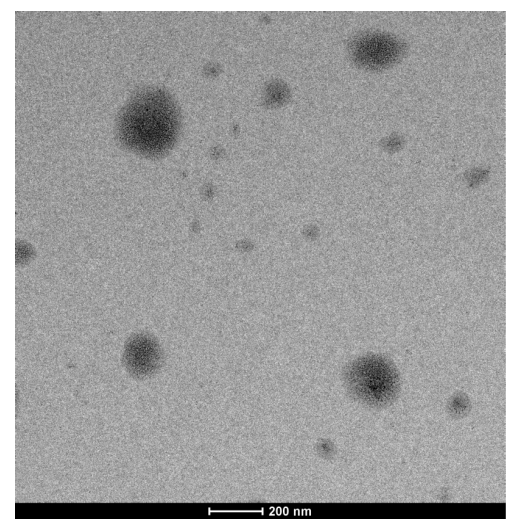

$c$

Fig. 1. TEM images of CdS/D-g-PAA samples. Inset scale bar is $50 \mathrm{~nm}(a), 100 \mathrm{~nm}(b), 200 \mathrm{~nm}(c)$

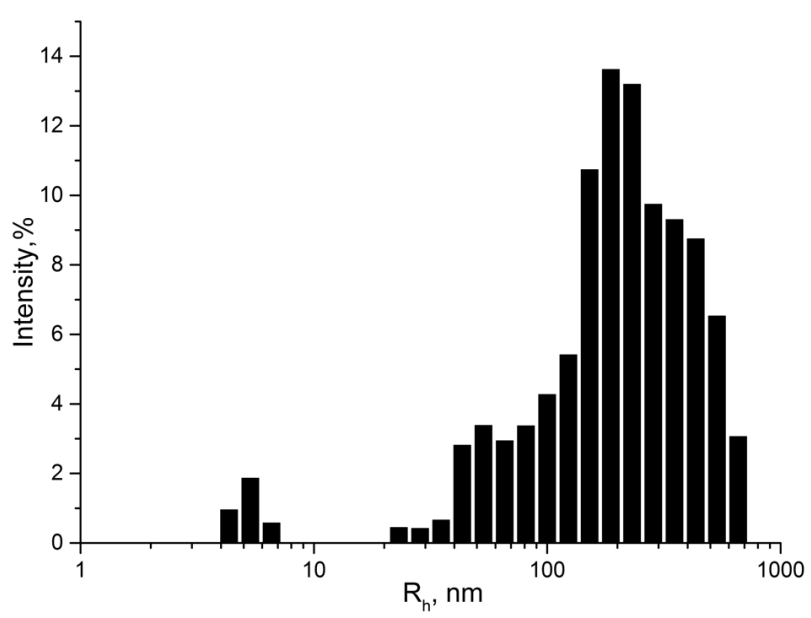

Fig. 2. Dynamic Light Scattering results

spherical (Fig. 1, a). It is seen that single CdS NPs are not dispersed regularly in the sol, but form local structures-clusters with the average size of 50-200 nm (Fig. 1, b-c).

The DLS results evaluated for this nanosystems show the existence of both single CdS nanoparticles of 4-6 $\mathrm{nm}$ and aggregates having the average size of $200 \mathrm{~nm}$ (Fig. 2). With regard for the TEM images, analysis of DLS results, molecular parameter of the polymer $\left(R_{g}=85 \mathrm{~nm}\right)$, and synthesis conditions, it can be suggested that the single CdS nanoparticles have been grown directly in the polymer molecule and form the clusters localized in a limited macromolecule volume.

The room temperature optical absorption spectrum of CdS/D-g-PAA hybrids dispersed in water is shown in Fig. 3, a. The absorption spectrum exhibits a broad absorption band between 350-550 nm, which is due to the first optically allowed transition of CdS between the electron states in the conduction band and the hole state in the valence band [19-21]. The obtained spectrum of CdS nanoparticles exhibits a blue shift comparing to the bulk CdS (540 nm) [4] caused by a decrease in the particle sizes. As is seen from Fig. 3, b, the absorption band displays the shoulder on the short-wavelength side and consists from at least three bands centered at 370, 403, and $448 \mathrm{~nm}$.

We have estimated the nanoparticle sizes from absorption spectra data and find, using the well-known Brus formula [22],

$\Delta E=2 \hbar^{2} \pi^{2} / d^{2} \mu-3.57 e^{2} / \epsilon d-0.124 e^{4} \mu / \hbar^{2} \epsilon^{2}$,

ISSN 2071-0194. Ukr. J. Phys. 2017. Vol. 62, No. 10 


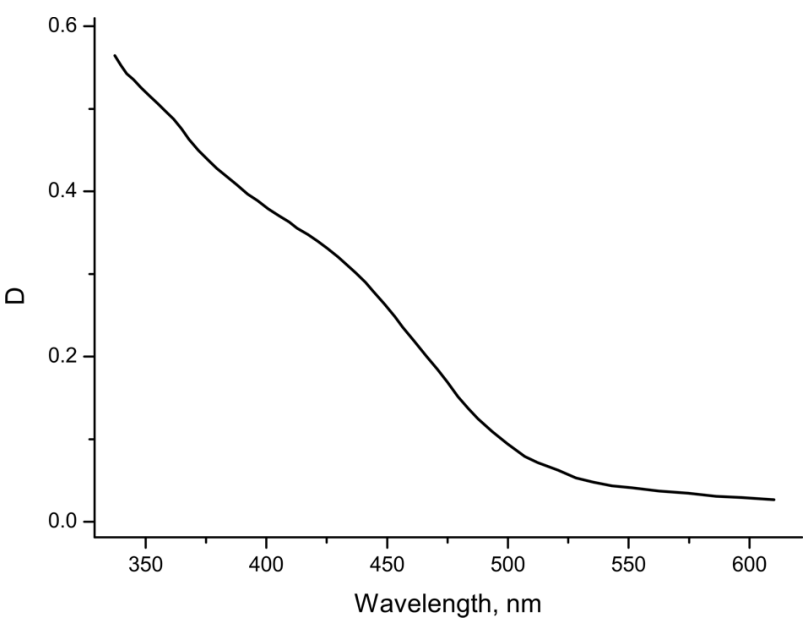

$a$

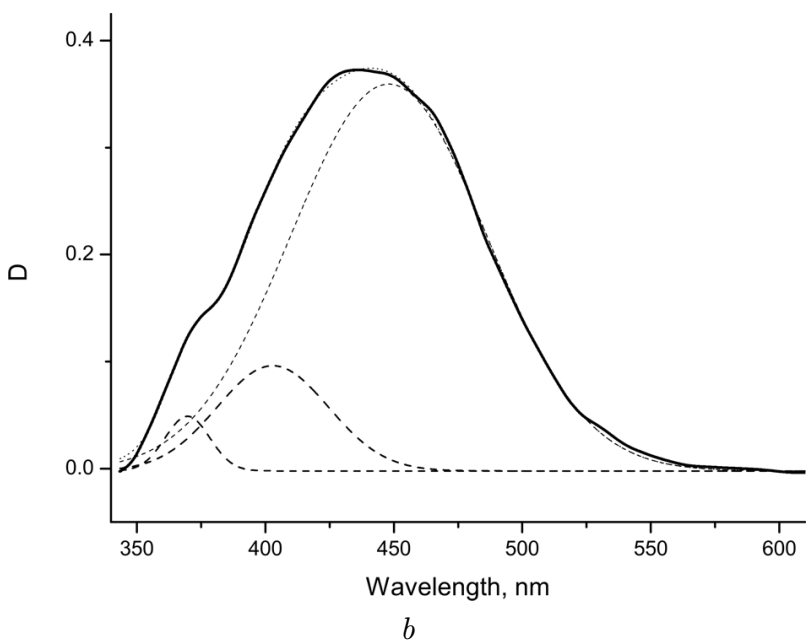

Fig. 3. Room temperature optical absorption spectra of CdS/D-g-PAA hybrids $(a)$ and the results of decomposition of the absorption band after the subtraction of a polymer absorption shoulder $(b)$

where $\Delta E=E_{g}(\mathrm{CdS})_{\text {nano }}-E_{g}(\mathrm{CdS})_{\text {bulk }}, \quad 1 / \mu=$ $=1 / m_{e}+1 / m_{h}, \epsilon$ is the dielectric constant of $\mathrm{CdS}$, and $d$ is the diameter of the nanoparticle.

The sizes of cadmium sulfide nanoparticles were also estimated using the empirical formula [23]

$d=-6.65 \times 10^{-8} \lambda^{3}+1.96 \times 10^{-4} \lambda^{2}-$

$-9.24 \times 10^{-2} \lambda+13.29$,

where $\lambda \mathrm{nm}$ is the position of the low-energy absorption band.

The calculations give the particle sizes of 2.6, 3.5, and $5.3 \mathrm{~nm}$.

ISSN 2071-0194. Ukr. J. Phys. 2017. Vol. 62, No. 10

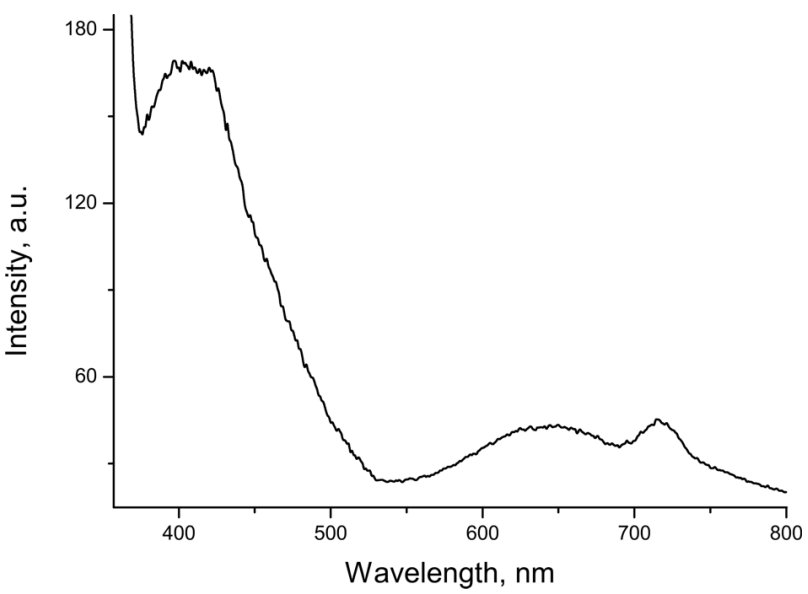

Fig. 4. Fluorescence emission spectra of CdS nanoparticles synthesized in star-like Dextran-graft-polyacrylamide matrices

The room temperature fluorescence spectrum of CdS nanoparticles is shown in Fig. 4. The spectrum consists of three bands centered at 408, 645, and $715 \mathrm{~nm}$. The emission at $408 \mathrm{~nm}$ is strong, is located at the absorption edge, and should be attributed to the excitonic fluorescence [8, 24]. The observed broad emission peaks at 645 and $715 \mathrm{~nm}$ are commonly attributed to the recombination of charged carriers trapped in the surface states and are related to the size of nanoparticles. The excitonic emission is much stronger than the trapped emission, by demonstrating a good surface passivation of particles.

\section{Conclusions}

This work presents a facile chemical precipitation synthesis route of cadmium sulfide nanoparticles at room temperature using star-like dextran-graft-polyacrylamide matrices. The size and shape of NPs are actually controlled by the choice of the reductant, protection agent, and synthesis conditions. The CdS nanoparticles synthesized into branched polymer matrices have been characterized using transmission electron microscopy, as well as the absorption and photoluminescent spectroscopy methods. It is revealed that CdS NPs are monodisperse, are $4-6 \mathrm{~nm}$ in size, and form clusters localized in a limited macromolecule volume of the polymer matrix. The results indicate that the preparation method is sufficiently efficient for removing the surface defects of CdS NPs. The prepared CdS nanoparticles revealed an improved blue light emission, and they may be considered as a promising material for light emitting devices, especially in the blue 
region. The prepared nanoparticles may have potential applications as biological labels.

1. A.D. Yoffe. Semiconductor quantum dots and related systems: Electronic, optical, luminescence and related properties of low dimensional systems. Adv. Phys. 50, 1 (2001).

2. N. Tessler, V. Medvedev, M. Kazes, S. Kan, U. Banin. Efficient Near-Infrared Polymer Nanocrystal Light-Emitting Diodes. Science 295, 1506 (2002).

3. G. Schmid (ed.). Nanoparticles. From Theory to Application (Wiley-VCH, 2004).

4. D.G. Thomas, J.J. Hopfield. Optical properties of bound exciton complexes in cadmium sulfide. Phys. Rev. 128, 2135 (1962).

5. D. Korbutyak, S. Kalytchuk, S. Budzulyak, A. Kuryk, S. Tokarev, O. Shevchuk, H. Ilchuk, V. Tokarev. Luminescent properties of CdS nanocrystals synthesized in polymeric matrices. J. Phys. Stidies 18, 1801 (2014).

6. D.V. Korbutyak, S.V. Tokarev, O.M. Shevchuk, H.A. Ilchuk, V.S. Tokarev, S.I. Budzulyak, A.O. Kuryk. Synthesis and photoluminescence spectra of the composite films with cadmium sulfide nanocrystals. J. of Nano- and Electr. Phys. 5, 04066 (2013).

7. S.V. Tokarev, G.A. Il'chuk, V.V. Kusnezh, O.M. Schevchuk, L.V. Dolyn'ska, V.S. Tokarev. Effect of a polymer matrix on the properties of CdS semiconductor clusters. Reports of the Nat. Acad. of Sci. of Ukraine 12, 58 (2011).

8. S. Sinha, I. Pan, P. Chanda, S.K. Sen. Nanoparticles fabrication using ambient biological resources. J. Appl. Biosci. 1, 1113 (2009).

9. M. Borovaya, Ya. Pirko, T. Krupodorova, A. Naumenko, Y. Blume, A. Yemets. Biosynthesis of cadmium sulfide quantum dots by using Pleurotus ostreatus (Jacq.) P. Kumm. Biotechnology \& Biotechnological Equipment 1 (2015).

10. M. Borovaya et al. Biosynthesis of luminescent CdS quantum dots using plant hairy root culture. Nanoscale Research Letters 9, 686 (2014).

11. N. Moloto, M.J. Moloto, N.J. Coville, S.S. Ray. The study on the time dependency and the stability of cobalt sulfide nanoparticles under an electron beam. J. of Nanoscience and Nanotechnology 10 (9), 5594 (2010).

12. X.M. Yang, G.M. Wang, Z.H. Lu. Characterization of CdS nanoparticles formed and aggregated in stearic acid Langmuir-Blodgett films by atomic force microscopy. Supramolecular Sci. 5, 549 (1998).

13. N.V. Kutsevol, T.N. Bezuglaya, N. Yu. Bezuglyi. Features of the intramolecular structure of branched polymer systems in solution. J. Struct. Chem. 55, 548 (2014).

14. N. Kutsevol, T. Bezugla, M. Bezuglyi, M. Rawiso. Branched Dextran-graft-Polyacrylamide Copolymers as Perspective Materials for Nanotechnology Macromol. Symp. 317-318 (1), 82 (2012).

15. N. Kutsevol, J.M. Guenet, N. Melnyk, D. Sarazin, C. Rochas. Solution properties of dextran-polyacrylamide graft copolymers. Polymer 47, 2061 (2006).

16. M. Bezuglyi, N. Kutsevol, M. Rawiso, T. Bezugla. Watersoluble branched copolymers dextran-polyacrylamide and their anionic derivates as matrices for metal nanoparticles in situ synthesis. Chemik 66, 862 (2012).

17. V. Chumachenko, N. Kutsevol, M. Rawiso, M. Schmutz, C. Blanck. In situ formation of silver nanoparticles in linear and branched polyelectrolyte matrices using various reducing agents. Nanoscale Research Lett. 9, 164 (2014).

18. N.V. Kutsevol, V.A. Chumachenko, M. Rawiso, V.F. Shkodich, O.V. Stoyanov. Star-like dextran-polyacrylamide polymers: Prospects of use in nanotechnologies. J. Struct. Chem. 56, 959 (2015).

19. H.S. Mansur, A.A.P. Mansur, J.C. Gonzalez. Synthesis and characterization of CdS quantum dots with carboxylicfunctionalized poly (vinyl alcohol) for bioconjugation. Polymer 52, 1045 (2011).

20. H.S. Mansur, A.A.P. Mansur, J.C. Gonzalez. Biomoleculequantum dot systems for bioconjugation applications. Colloid Surfaces B 84, 360 (2011).

21. X. Peng, J. Wickham, A.P. Alivisatos. Kinetics of II-VI and III-V colloidal semiconductor nanocrystal growth: "Focusing" of size distributions. J. Am. Chem. Soc. 120, 5343 (1998).

22. L.E. Brus. Electron-electron and electron-hole interactions in small semiconductor crystallites: The size dependence of the lowest excited electronic state. J. Chem. Phys. 80, 4403 (1984).

23. W. Yu, L. Qu, W. Guo, X. Peng. Experimental determination of the extinction coefficient of CdTe, CdSe, and CdS nanocrystals. Chem. Mater. 15, 2854 (2003).

24. E. Eychmuller, A. Hasselbarth, L. Katsikas, H. Weller. Photochemistry of semiconductor colloids. 36. Fluorescence investigations on the nature of electron and hole traps in Q-sized colloidal CdS particles. Ber. Bunsenges. Phys. Chem. 95, 79 (1991).

Received 26.09.15

А.П. Науменко, Н.В. Куцевол, В.А. Чумаченко,

В.Г. Пащенко, С.Ю. Кутовий, М. Равізо

СИНТЕЗ ТА ХАРАКТЕРИЗАЦІЯ ЗОЛІВ CdS,

ОТРИМАНИХ В РОЗГАЛУЖЕНИХ МАТРИЦЯХ ДЕКСТРАНПОЛІАКРИЛАМІД

$\mathrm{P}$ е $з$ ю м е

Наночастинки (НЧ) сульфіду кадмію (CdS) були синтезовані в розгалудженій полімерній матриці декстранполіакриламід. Отриманий стабільний золь було охарактеризовано методами спектрофотометрії, флюоресценції, трансмісійної електронної мікроскопї та динамічного розсіювання світла. Полімер впливав на процес формування наночастинок, а саме - контролював їх розмір, морфологію та забезпечував їхню стабільність при зберіганні, запобігаючи агрегації наночастинок. Було показано, що отримані в розгалуженій полімерній матриці $\mathrm{CdS}$ НЧ були монодисперсними з розміром 4-6 нм та утворювали кластери (50200 нм), локалізовані в обмеженому об'ємі макромолекули. $\mathrm{CdS}-$ наночастинки показали покращену емісію, вони є перспективним матеріалом для світловипромінюючих пристроїв, особливо для синьої ділянки спектра. Також вони можуть знайти застосування як біологічні маркери. 